\title{
The influence of forest types on manganese content in soils
}

\author{
Panagiotis Michopoulos $^{1} \bowtie$, Marios Kostakis $^{2}$, Nikolaos S. Thomaidis ${ }^{2}$, Ioannis Pasias ${ }^{2}$ \\ ${ }^{1}$ Institute of Mediterranean Forest Ecosystems, Hellenic Agricultural Organization DEMETER, Terma Alkmanos, \\ Athens 115 28, Greece, e-mail: mipa@fria.gr \\ ${ }^{2}$ National and Kapodistrian University of Athens, Department of Chemistry, Laboratory of Analytical Chemistry, \\ Athens 157 71, Greece
}

\begin{abstract}
The concentrations of available and total $\mathrm{Mn}$ were determined in the soils of three different forest ecosystems, i.e. a maquis forest, a beech forest and fir one. The concentrations of total Mn in the deeper mineral horizons reflected the type of patent material, but in the surface layers, the more acidic soil (in the beech forest) had the higher concentrations. This was due to the high concentrations of $\mathrm{Mn}$ in the standing leaves and litterfall of beech trees, which brought about high litterfall fluxes of $\mathrm{Mn}$ in that forest. However, the concentrations of (DTPA) available Mn was significantly higher in the soil under beech only in the $0-10 \mathrm{~cm}$ layer, whereas the fast decomposition of organic matter in the Mediterranean zone resulted in higher concentrations of available $\mathrm{Mn}$ in the Ofh soil horizon of the maquis plot. The available Mn did not correlate with soil $\mathrm{pH}$. These findings mean that high concentrations of available $\mathrm{Mn}$ do not always entail higher uptake. The soil $\mathrm{pH}$ played a predominant role for the high concentrations in the vegetation of the beech forest.
\end{abstract}

\section{KeY WORDS}

manganese, soil, forest, litterfall

\section{INTRODUCTION}

Manganese (Mn) is an essential micronutrient for plant growth. It is a component of enzymes taking part in photosynthesis and other processes. Mn is also part of an important antioxidant (superoxide dismutase) structure that protects plant cells by neutralising free radicals harmful for plant tissues (Musavi et al. 2011).

Despite the important role in plant physiology, $\mathrm{Mn}$ can have adverse effects on plant growth when the uptake of the metal is high. Although expression of $\mathrm{Mn}$ toxicity varies considerably among plant species, brown spots on older leaves surrounded by chlorotic zones are typical symptoms of Mn toxicity (El-Jaoual and Cox 1998). In addition, excessive Mn uptake was shown to inhibit $\mathrm{Ca}$ and $\mathrm{Mg}$ uptake (Maas et al. 1969). Two factors are crucial for Mn enrichment in soil solution: soil redox potential and $\mathrm{pH}$. Low redox potential (anoxic conditions in waterlogged soils) brings about dissolution of $\mathrm{Fe}$ and $\mathrm{Mn}$ oxides and enrichment of soil solution with $\mathrm{Mn}^{2+}$. A classic example is the paddy soils (Matin and Jalali 2017). Low $\mathrm{pH}$ is another important factor that contributes to enhanced Mn uptake. In most cases, forest soils are aerobic, rendering $\mathrm{pH}$ the predominant 
environmental variable affecting Mn mobility. Mobility is the ability of Mn to enter the soil solution due to the dissolution of Mn oxides through the reactions with hydrogen ions. The $\mathrm{pH} 5.5$ is a threshold value because Mn oxides solubilise and release $\mathrm{Mn}^{2+}$ into the soil solution (Porter et al. 2004). In high-pH aerated soils, other factors are important so that plants do not suffer from Mn deficiency. Organic compounds capable of Mn and exudation of $\mathrm{H}^{+}$lowering the $\mathrm{pH}$ of alkaline soils can increase Mn availability (Rengel 2015).

The critical Mn concentration in leaves associated with injury varies among plant species and varieties within species, due to wide differences in $\mathrm{Mn}$ tolerance (Ohki 1981). El-Jaoual and Cox (1998) quoted a table containing critical toxicity levels of $\mathrm{Mn}$ in the leaves of various agricultural plants. The lowest limit was $160 \mathrm{mg} \mathrm{kg}^{-1}$ in soybeans, and the highest $7,100-9,600 \mathrm{mg} \mathrm{kg}^{-1}$ in carrots.

Park and Yanai (2009) found that in the leaves of the American beech (Fagus grandifolia Ehrh.) in two adjacent catchments in the Adirondack region of New York State, USA, the Mn concentrations in leaves were not correlated with the concentrations of total Mn but only with $\mathrm{pH}$. It was showed that an increase of $\mathrm{pH}$ after liming caused a decrease in available $\mathrm{Mn}$ in forest soils (Grønflaten et al. 2005) and a decrease in Mn concentrations in the needles of Scots pine (Derome 2000). Soil $\mathrm{pH}$ exerts so strong an influence on Mn uptake that even a mor-type humus can supply more Mn because of the lower soil pH. Astrup and Bulow Olsen (1979) found that $\mathrm{Mn}$ uptake by beech in a mor humus site $(\mathrm{pH} 4.1)$ was $8.7 \mathrm{~kg} \mathrm{ha}^{-1} \mathrm{yr}^{-1}$, whereas in the mull type ( $\mathrm{pH} 5.3$ ), the uptake was $2.8 \mathrm{~kg} \mathrm{ha}^{-1} \mathrm{yr}^{-1}$. Wyttenbach et al. (1991) determined the concentrations of 21 elements in oneyear-old needles of Norway spruce at 39 different sites. They found that the needle contents of Mn showed the largest dependence on soil $\mathrm{pH}$ of all the elements, regardless of soil type or geology. The effect of $\mathrm{pH}$ on Mn uptake was also shown in the case of a mountainous Greek fir (Abies cephalonica, Loudon) (Michopoulos et al. 2004). When the soil $\mathrm{pH}$ was higher than 7 , the needles had a $\mathrm{Mn}$ range of 20 to $83 \mathrm{mg} \mathrm{kg}^{-1}$. When the pH dropped below 7 (but not below 6), the range went higher (166-865 mg kg-1).

The aim of this work was to assess the percentage of the available and total $\mathrm{Mn}$ in the soils of three different forest types. The motivation to carry out this work was the high concentrations of $\mathrm{Mn}$ found in beech leaves. The hypothesis was that high Mn concentrations in tree leaves together with high Mn fluxes in litterfall are related with high concentrations of available $\mathrm{Mn}$ in soils.

\section{Material AND Methods}

\section{Sites description}

All sites from which the material was selected take part in the Intensive Monitoring Survey of the ICP Forests network (International Co-operative Programme on Assessment and Monitoring of Air Pollution Effects on Forests). The sites represent important ecosystems in Greece, and they were selected along a line crossing central Greece. The maquis stand is situated in western Greece (Lat. 38.846111, Long. 21.305), the fir (Abies borisii-regis Mattf) plot in the centre (Lat. 38.874444, Long. 21.965833) and the beech (Fagus sylvatica L.) stand in the north-eastern Greece (Lat. 39.797778, Long. 22.777222). The fir and the beech stands are considered mountainous, whereas the maquis stand is in the Mediterranean ecological zone. The term "maquis" is defined as "a scrubland vegetation of the Mediterranean region composed primarily of leathery, broadleaved evergreen shrubs or small trees" (Encyclopaedia Britannica 2020). Information about the study sites is given in Table 1.

Table 1. Characteristics of the areas from which the soil samples were selected

\begin{tabular}{|l|l|l|l|l|}
\hline Area & $\begin{array}{l}\text { 导 } \\
\text { 导 }\end{array}$ & $\begin{array}{c}\text { Soil } \\
\text { parent } \\
\text { material }\end{array}$ & $\begin{array}{l}\text { Soil type } \\
\text { (FAO } \\
1988)\end{array}$ & \multicolumn{1}{|c|}{ Vegetation } \\
\hline Amfilohia & 360 & $\begin{array}{l}\text { Sandy } \\
\text { flysch }\end{array}$ & $\begin{array}{l}\text { Haplic } \\
\text { Luvisol }\end{array}$ & $\begin{array}{l}\text { Quercus ilex, L., } \\
\text { Arbutus } \text { unedo, L. } \\
\text { Phyllirea latifolia, L. }\end{array}$ \\
\hline $\begin{array}{l}\text { Ossa- } \\
\text { Mountain }\end{array}$ & 890 & $\begin{array}{l}\text { Mica } \\
\text { schist }\end{array}$ & $\begin{array}{l}\text { Haplic } \\
\text { Alisol }\end{array}$ & Fagus sylvatica, L. \\
\hline Karpenisi & 1170 & $\begin{array}{l}\text { Argil- } \\
\text { laceus } \\
\text { flysch }\end{array}$ & $\begin{array}{l}\text { Humic } \\
\text { Alisol }\end{array}$ & $\begin{array}{l}\text { Abies borisii-regis, } \\
\text { M. }\end{array}$ \\
\hline
\end{tabular}

\section{Leaf, litterfall and soil collection}

One-year leaf and needle samples were collected from the upper part of the crown from five dominant trees chosen at random in each site and formed a pooled sam- 
ple. The leaves from beach (Fagus sylvatica L.) trees are collected each summer, whereas those of the holm oak (Quercus ilex L.) and Bulgarian fir (Abies borisii regis Mattf.) in December (dormant period). The collection has been done every two years since 1995 . The last one was carried out in 2019. So, in total, there were 13 leaves samples from each plot.

Litterfall, the plant material fallen to the ground from tree canopies, was collected in 10 plastic litter traps inside the forest stands each having an area of $0.242 \mathrm{~m}^{2}$. The litter traps were placed in a straight line at a distance of $10 \mathrm{~m}$ from each other. All fractions (leaves, twigs, lichens and rest) were collected, and in the laboratory, they were separated and analysed. The litterfall sampling for the fir and beech plots covered the period between 2009 and 2017 and for the maquis plot the years 2013 to 2017. With regard to the maquis stand, it has to be clarified that for litterfall, all tree species described in Table 1 were included, whereas as mentioned, living leaves were collected only from the holm oak trees.

Soil samples were collected by means of systematic sampling. The excavation positions were some meters away from the position of the sampled trees. Inside each plot, along three lines distancing $25 \mathrm{~m}$ from each other six soil pits were excavated. Each pit was $5 \mathrm{~m}$ away from each other. From each soil pit, the samples collected were the $\mathrm{Ol}$ and Ofh horizons with a frame $15 \times 15 \mathrm{~cm}$ and mineral soil layers from the depths $0-10 \mathrm{~cm}, 10-20 \mathrm{~cm}, 20-40 \mathrm{~cm}$ and $40-80 \mathrm{~cm}$. There was mixture of six samples of equal volume per horizon and soil depth to have three pooled samples per horizon and depth.

\section{Sample pre-treatment}

The leaves and litterfall material were dried at $80^{\circ} \mathrm{C}$ for 48 hours and ground. The soil samples were air dried and passed through a $2 \mathrm{~mm}$ sieve (apart from the $\mathrm{Ol}$ horizon). Subsamples of the sieved material were pulverized in a ball mill for the total Mn analysis.

\section{Physical and chemical analysis}

Leaf samples together with litterfall material were ground and digested in a mixture of $\mathrm{HNO}_{3}-\mathrm{HClO}_{4}$ in a proportion of 2:1 (v:v). The concentrations of $\mathrm{Mn}$ in the digests were determined with a flame atomic absorption spectrophotometer using a mixture of air and acetylene. The quality of the analysis was checked by analysing the reference plant material provided by the foliar coordination centre of the ICP programme (UNICP-Forests 2020).

The soil $\mathrm{pH}$ was determined by a glass electrode in a mixture of soil and water at a ratio of 1:5 (volume per volume). The soil texture was determined by the pipette method. The concentrations of organic $\mathrm{C}$ were determined by a $\mathrm{C}$ analyser (model VARIO MAX, Elememtar Company) through dry combustion.

Exchangeable cations in the Ofh and mineral soil layers were extracted with a $0.1 \mathrm{M}$ unbuffered $\mathrm{BaCl}_{2}$ solution, and their concentrations were determined with an ICP-MS instrument (Thermo iCAP Qc). The calculated exchangeable cations were added to fond the cation exchange capacity (CEC).

For the determination of total $\mathrm{Mn}$ in soils, pulverised soil material was digested in a microwave oven with $\mathrm{HF}$ and aqua regia at a temperature range of $160-170^{\circ} \mathrm{C}$ for $20 \mathrm{~min}$. The $\mathrm{Mn}$ concentrations in the digests were measured with the same ICP-MS instrument mentioned above. The quality assurance of the Mn analysis was checked with the same plant material used for the flame atomic absorption spectrophotometer.

Available Mn in soils was extracted with a diethylene tetramine penta acetic acid (DTPA) solution (Lindsay and Norvell, 1978) and its concentrations were measured with atomic absorption spectrophotometer (Perkin Elmer 3110). It is a widespread procedure to use a single extractant to determine available concentrations of micronutrients in soils. The DTPA has been used to measure Mn concentrations in agricultural soils (Mahmoudabadi et al. 2015; Sharma et al. 2011).

All results (in both leaves and soils) are expressed in oven dry weight at $105^{\circ} \mathrm{C}$.

\section{Calculations and statistical analysis}

The averages of soil properties together with Mn concentrations in vegetation and soils were calculated together with the coefficients of variations as the percentages of the standard deviations over the means. Specifically, for the litterfall, it was the weighted means of $\mathrm{Mn}$ based on masses that were calculated. 
The annual litterfall fluxes of $\mathrm{Mn}$ in the three forest types were estimated for all fractions of litterfall: foliar, woody (twigs, branches and tree bark) and rest (mosses, lichens, fruits and flowers). The litterfall fractions were calculated taking into account the Mn concentrations, the total mass of litterfall and the area of the litter traps. After the calculations, the litterfall fluxes of $\mathrm{Mn}$ in all fractions were added to have the total litterfall fluxes of $\mathrm{Mn}$.

For the statistical comparisons with analysis of variance (ANOVA), the variability had to be reduced to achieve as much as possible a normal distribution. The concentrations of $\mathrm{Mn}$ in leaves and in litterfall were compared with a one-way ANOVA. Also, with the oneway ANOVA, the comparison among the fluxes of $\mathrm{Mn}$ in litterfall was carried out.

An additional statistical comparison was made among the concentrations of total $\mathrm{Mn}$ in the soil layers of the three forest types. The respective comparison was also made for the available Mn. For all the statistical comparisons, the least significant difference (LSD) test was used to compare the means.

Pearson correlation coefficients were applied (after the log transformation of data) between the available $\mathrm{Mn}$ and the soil properties, including the total Mn.

\section{Results}

The average concentrations of $\mathrm{Mn}$ in leaves and litterfall, as well as the average fluxes of Mn in litterfall were significantly higher in the beech stand (Tab. 2). Among all soil properties (Tab. 3), the $\mathrm{pH}$ had the lowest coefficient of variation. In all forest stands, the concentrations of total and available Mn had the highest values in the FH horizons (Tab. 4) evidence of the effect of organic matter in soils (Tab. 3). In the beech stand, the concentration of total $\mathrm{Mn}$ in the FH horizon was very high, more than twice the magnitude of the other forest types. The comparison of the concentrations of available $\mathrm{Mn}$ among the three forest types (Tab. 4) had various results. The maquis stand had the highest values in the FH horizon. In the next layer $0-10 \mathrm{~cm}$, it was the beech stand, and in deeper soil, the beech and the fir plot did not differ significantly.
Table 2. Concentrations ( $\left.\mathrm{mg} \mathrm{kg}^{-1}\right)$ of $\mathrm{Mn}$ in standing leaves and litterfall as well as fluxes of $\mathrm{Mn}\left(\mathrm{kg} \mathrm{ha}^{-1} \mathrm{yr}^{-1}\right)$ in the litterfall in the three forested plots. Values with different letters in the same row differ significantly for at least 0.05 probability level

\begin{tabular}{|c|c|c|c|}
\hline \multicolumn{5}{|c|}{$\begin{array}{c}\text { Standing leaves of the dominant trees } \\
\text { in the three forested stands }\end{array}$} \\
\hline \multirow{3}{*}{ Average } & Holm oak & Beech & Fir \\
\cline { 2 - 4 } & $561 \mathrm{a}$ & $1876 \mathrm{~b}$ & $299 \mathrm{a}$ \\
\cline { 2 - 4 } & $(33)$ & $(13)$ & $(33)$ \\
\hline \multirow{4}{*}{ Average } & \multicolumn{4}{|c|}{ Litterfall } & Fir \\
\cline { 2 - 4 } & Maquis & Beech & $354 \mathrm{a}$ \\
\cline { 2 - 4 } & $405 \mathrm{a}$ & $1475 \mathrm{~b}$ & $(15)$ \\
\hline \multirow{4}{*}{ Average } & $(23)$ & $(19)$ & Fir \\
\cline { 2 - 5 } & $2.00 \mathrm{a}$ & $7.66 \mathrm{~b}$ & $2.09 \mathrm{a}$ \\
\cline { 2 - 5 } & $(29)$ & $(26)$ & $(29)$ \\
\hline
\end{tabular}

Values in parentheses denote coefficients(\%) of variation.

Table 3. Selected soil properties in the soil layers of the three forested stands. Clay and CEC are expressed in percentages (\%) and CEC in meq/100 $\mathrm{g}$ of soil

\begin{tabular}{|c|c|c|c|c|}
\hline Layer & $\mathrm{pH}$ & Clay & CEC & $\mathrm{C}$ \\
\hline 1 & 2 & 3 & 4 & 5 \\
\hline \multicolumn{5}{|c|}{ Maquis } \\
\hline $\mathrm{L}$ & & & & $\begin{array}{l}49.4 \\
(2.8)\end{array}$ \\
\hline FH & $\begin{array}{c}6.6 \\
(3.7)\end{array}$ & & $\begin{array}{l}71.6 \\
(8.1)\end{array}$ & $\begin{array}{l}26.0 \\
(7.1)\end{array}$ \\
\hline $0-10 \mathrm{~cm}$ & $\begin{array}{l}6.26 \\
(2.0)\end{array}$ & $\begin{array}{l}23.6 \\
(6.2)\end{array}$ & $\begin{array}{l}24.5 \\
(12)\end{array}$ & $\begin{array}{c}5.0 \\
(14)\end{array}$ \\
\hline $10-20 \mathrm{~cm}$ & $\begin{array}{l}6.18 \\
(6.6)\end{array}$ & $\begin{array}{l}24.2 \\
(14)\end{array}$ & $\begin{array}{l}15.8 \\
(20)\end{array}$ & $\begin{array}{l}2.73 \\
(17)\end{array}$ \\
\hline $20-40$ & $\begin{array}{l}6.12 \\
(2.3)\end{array}$ & $\begin{array}{l}26.0 \\
(19)\end{array}$ & $\begin{array}{l}12.8 \\
(11)\end{array}$ & $\begin{array}{l}1.44 \\
(17)\end{array}$ \\
\hline $40-80$ & $\begin{array}{l}6.53 \\
(5.7)\end{array}$ & $\begin{array}{l}29.3 \\
(15)\end{array}$ & $\begin{array}{l}13.7 \\
(13)\end{array}$ & $\begin{array}{l}0.86 \\
(14)\end{array}$ \\
\hline \multicolumn{5}{|c|}{ Beech } \\
\hline $\mathrm{L}$ & & & & $\begin{array}{l}47.3 \\
(0.6)\end{array}$ \\
\hline $\mathrm{FH}$ & $\begin{array}{l}5.75 \\
(4.9)\end{array}$ & & $\begin{array}{l}41.2 \\
(12)\end{array}$ & $\begin{array}{l}26.9 \\
(3.5)\end{array}$ \\
\hline $0-10 \mathrm{~cm}$ & $\begin{array}{l}4.83 \\
(2.4)\end{array}$ & $\begin{array}{l}20.0 \\
(5.5)\end{array}$ & $\begin{array}{l}2.13 \\
(18)\end{array}$ & $\begin{array}{l}4.32 \\
(4.5)\end{array}$ \\
\hline
\end{tabular}




\begin{tabular}{|c|c|c|c|c|}
\hline 1 & 2 & 3 & 4 & 5 \\
\hline $10-20 \mathrm{~cm}$ & $\begin{array}{l}5.08 \\
(2.1)\end{array}$ & 21.8 & $\begin{array}{l}1.44 \\
(9.2)\end{array}$ & $\begin{array}{l}2.95 \\
(8.7)\end{array}$ \\
\hline $20-40 \mathrm{~cm}$ & $\begin{array}{l}5.24 \\
(0.6)\end{array}$ & $\begin{array}{l}21.5 \\
(0.3)\end{array}$ & $\begin{array}{l}1.20 \\
(4.8)\end{array}$ & $\begin{array}{l}2.09 \\
(12)\end{array}$ \\
\hline $40-80 \mathrm{~cm}$ & $\begin{array}{l}5.27 \\
(1.1)\end{array}$ & $\begin{array}{c}15 \\
(4.1)\end{array}$ & $\begin{array}{c}0.973 \\
(9.3)\end{array}$ & $\begin{array}{l}0.91 \\
(3.2)\end{array}$ \\
\hline \multicolumn{5}{|c|}{ Fir } \\
\hline $\mathrm{L}$ & & & & $\begin{array}{l}50.8 \\
(0.7)\end{array}$ \\
\hline $\mathrm{FH}$ & $\begin{array}{l}6.48 \\
(0.2)\end{array}$ & & $\begin{array}{l}57.8 \\
(9.5)\end{array}$ & $\begin{array}{l}23.0 \\
(14)\end{array}$ \\
\hline $0-10 \mathrm{~cm}$ & $\begin{array}{l}6.07 \\
(2.0)\end{array}$ & $\begin{array}{l}27.2 \\
(2.0)\end{array}$ & $\begin{array}{l}17.9 \\
(15)\end{array}$ & $\begin{array}{l}5.12 \\
(20)\end{array}$ \\
\hline $10-20 \mathrm{~cm}$ & $\begin{array}{l}5.77 \\
(3.1)\end{array}$ & $\begin{array}{l}31.2 \\
(2.1)\end{array}$ & $\begin{array}{l}10.9 \\
(15)\end{array}$ & $\begin{array}{l}3.36 \\
(10)\end{array}$ \\
\hline $20-40 \mathrm{~cm}$ & $\begin{array}{l}5.54 \\
(1.2)\end{array}$ & $\begin{array}{l}33.0 \\
(6.7)\end{array}$ & $\begin{array}{c}7.5 \\
(7.9)\end{array}$ & $\begin{array}{l}2.75 \\
(3.5)\end{array}$ \\
\hline $40-80 \mathrm{~cm}$ & $\begin{array}{l}5.32 \\
(1.5)\end{array}$ & $\begin{array}{l}34.9 \\
(14)\end{array}$ & $\begin{array}{c}3.8 \\
(15)\end{array}$ & $\begin{array}{l}1.53 \\
(19)\end{array}$ \\
\hline
\end{tabular}

Values in parentheses denote coefficients of variation (\%).

Table 4. Concentrations $\left(\mathrm{mg} \mathrm{kg}^{-1}\right)$ of total and available Mn in the soil layers of the three-forested stands. Values with different letters in the same row differ significantly for at least 0.05 probability level

\begin{tabular}{|c|c|c|c|}
\hline & Maquis & Beech & Fir \\
\hline 1 & 2 & 4 & 4 \\
\hline \multicolumn{4}{|c|}{ Total Mn } \\
\hline $\mathrm{L}$ & $\begin{array}{c}306 \mathrm{a} \\
(65)\end{array}$ & $\begin{array}{c}1745 \mathrm{~b} \\
(12)\end{array}$ & $\begin{array}{c}613 \mathrm{a} \\
(52)\end{array}$ \\
\hline $\mathrm{FH}$ & $\begin{array}{c}1790 \mathrm{a} \\
(12)\end{array}$ & $\begin{array}{c}4398 \mathrm{~b} \\
(10)\end{array}$ & $\begin{array}{c}1730 \mathrm{a} \\
(4.2)\end{array}$ \\
\hline $0-10 \mathrm{~cm}$ & $\begin{array}{c}687 \mathrm{a} \\
(13)\end{array}$ & $\begin{array}{c}1130 \mathrm{~b} \\
(12)\end{array}$ & $\begin{array}{c}1208 \mathrm{bc} \\
(6.3)\end{array}$ \\
\hline $10-20 \mathrm{~cm}$ & $\begin{array}{l}607 \mathrm{a} \\
(7.0)\end{array}$ & $\begin{array}{c}842 \mathrm{ab} \\
(4.7)\end{array}$ & $\begin{array}{c}969 \mathrm{~b} \\
(26)\end{array}$ \\
\hline $20-40 \mathrm{~cm}$ & $\begin{array}{l}665 \mathrm{a} \\
(6.8)\end{array}$ & $\begin{array}{c}1087 b c \\
(7.0)\end{array}$ & $\begin{array}{c}1015 \mathrm{c} \\
(30)\end{array}$ \\
\hline $40-80 \mathrm{~cm}$ & $\begin{array}{l}644 \mathrm{a} \\
(5.1)\end{array}$ & $\begin{array}{c}697 \mathrm{a} \\
(13)\end{array}$ & $\begin{array}{c}650 \mathrm{a} \\
(49)\end{array}$ \\
\hline \multicolumn{4}{|c|}{ Available Mn } \\
\hline FH & $\begin{array}{c}738 \mathrm{a} \\
(21)\end{array}$ & $\begin{array}{c}561 \mathrm{~b} \\
(20)\end{array}$ & $\begin{array}{c}370 \mathrm{c} \\
(21)\end{array}$ \\
\hline $0-10 \mathrm{~cm}$ & $\begin{array}{c}114 \mathrm{a} \\
(15)\end{array}$ & $\begin{array}{c}196 \mathrm{~b} \\
(11)\end{array}$ & $\begin{array}{c}151 \mathrm{c} \\
(15)\end{array}$ \\
\hline $10-20 \mathrm{~cm}$ & $\begin{array}{l}95.4 \mathrm{a} \\
(62.8)\end{array}$ & $\begin{array}{l}148 \mathrm{~b} \\
(6.8)\end{array}$ & $\begin{array}{c}116 \mathrm{ab} \\
(14)\end{array}$ \\
\hline
\end{tabular}

\begin{tabular}{|c|c|c|c|}
\hline 1 & 2 & 4 & 4 \\
\hline \multirow{2}{*}{$20-40 \mathrm{~cm}$} & $62.8 \mathrm{a}$ & $113 \mathrm{~b}$ & $92.6 \mathrm{~b}$ \\
& $(5.9)$ & $(4.5)$ & $(28)$ \\
\hline \multirow{2}{*}{$40-80 \mathrm{~cm}$} & $61.5 \mathrm{a}$ & $46.2 \mathrm{a}$ & $56.6 \mathrm{a}$ \\
& $(24)$ & $(24)$ & $(40)$ \\
\hline
\end{tabular}

Values in parentheses denote coefficients of variation (\%).

The Pearson correlation coefficients (Tab. 5) showed that the concentrations of available Mn correlated significantly with the organic $\mathrm{C}$, cation exchange capacity and total Mn.

Table 5. Pearson correlation coefficients between available Mn and soil properties

\begin{tabular}{|l|c|c|c|c|c|}
\hline & CEC & $\mathrm{pH}$ & Clay & Organic C & Total Mn \\
\hline $\begin{array}{l}\text { Available } \\
\text { Mn }\end{array}$ & $0.588 *$ & 0.264 & -0.62 & $0.962 * *$ & $0.867 * *$ \\
\hline
\end{tabular}

* and ** mean significant correlations for 0.05 and 0.01 probability levels, respectively.

\section{Discussion}

\section{Plant tissues}

The concentrations of $\mathrm{Mn}$ in the leaves of beech in our work are high, considering that the range of the average concentrations in beech leaves in forests of central Europe was found 555-935 mg kg-1 (EC-UN/ ECE-FBVA 1997). Kabata-Pendias and Pendias (2000) found a toxicity limit of $500 \mathrm{mg} \mathrm{kg}^{-1}$ some agricultural plants, but a normal concentration of $740 \mathrm{mg}$ $\mathrm{kg}^{-1}$ grasses in a pine forest on acid soil. It seems that plants in the wild can adapt to high Mn concentrations in their tissues. In any case, symptoms (brown spots or chlorotic zones) of Mn toxicity have not been observed. High concentrations of $\mathrm{Mn}$ in beech leaves have also been found by other researchers. Duquesnay et al. (2000) found a range 1,033-1,701 $\mathrm{mg} \mathrm{kg}^{-1}$ in beech leaves in 118 forest stands in northwest France. GlatzeI and Kazda (1985) found even higher concentrations $\left(2,600 \mathrm{mg} \mathrm{kg}^{-1}\right)$ in beech leaves in acid soils in Germany. It might be argued that fir and holm oak species cannot take up as substantial amounts of $\mathrm{Mn}$ as beech trees. This argument, however, does not correspond to reality. Madejón et al. (2006) found an approximate $\mathrm{Mn}$ concentration of $1,000 \mathrm{mg} \mathrm{kg}^{-1}$ in the leaves of holm oak grown in acid soils in SW Spain. 
Gandois et al. (2012) found a relatively higher Mn concentration $\left(373 \mathrm{mg} \mathrm{kg}^{-1}\right)$ than those in our work in the needles of silver fir in the Pyrenees Mountains in the south of France in soils of a rather high pH (6.6 to 8.3). Even much higher Mn concentrations were measured for other conifers. Parzych et al. (2017) found a range of 587 to $716 \mathrm{mg} \mathrm{kg}^{-1}$ in the needles of Pinus banksiana. Norway spruce accumulated $4,000 \mathrm{mg} \mathrm{kg}^{-1}$ (Kazda and Zvacek, 1985). Therefore, it can be inferred that high Mn uptake is not a question only of species. Dry deposition of Mn can play a role on Mn enrichment when a source of $\mathrm{Mn}$ is close to a forest. Manganese, $\mathrm{Fe}$ and $\mathrm{Cr}$ are elements that do not travel far from their emission sources (Steiness and Friedland 2005). The three forest types in our work are not close to any industrial activity, so we can infer that the only dry deposition form can be derived from local soil during windy days (which cannot be ignored).

Mn concentrations in litterfall followed those in leaves. The beech stand again had significantly higher concentrations than the other species. Even higher concentrations $\left(2,929-4,711 \mathrm{mg} \mathrm{kg}^{-1}\right)$ than those in our work of Mn were found in beech litterfall in a mixed forest grown on acid soils in northern Poland by Jonczak and Parzych (2014). High Mn concentrations in litterfall tissue entail high amounts of $\mathrm{Mn}$ in litterfall. In Table 2, the fluxes of $\mathrm{Mn}$ in beech litterfall were found almost four times as high as the other forest types. The influence of this fact is showed in the top layers in soils.

\section{Soils}

Total Mn

The significantly higher litterfall fluxes of $\mathrm{Mn}$ in the beech stand reflect the significantly higher concentrations of total $\mathrm{Mn}$ in the organic layers $\mathrm{Ol}$ and $\mathrm{Ofh}$ (Tab. 4). It can be noticed that below the organic layer $\mathrm{FH}$, the concentrations of total $\mathrm{Mn}$ in the beech plot do not differ significantly from that in the fir plot (Tab. 4). The lowest concentrations of total $\mathrm{Mn}$ in the mineral layers were found in the maquis plot probably reflecting the nature of parent material. Both the fir and the maquis plots are situated on flysch parent material. In turn, the nature of the flysch (Tab. 1) either sandy or argillaceous greatly determines some soil properties. For example, in Table 2, the clay percentage is higher in the soil of the fir plot. Manganese oxides very often form coatings around soil particles of clay size and therefore enrich soils with Mn. Nakos (1983) also found similar concentrations of total $\mathrm{Mn}$ in soils developed on sandy flysch. In the deepest soil layer $(40-80 \mathrm{~cm})$, there was no significant difference among the three plots. In general, the elemental concentrations in deep soil depths represent the elemental content of the parent material. The Mn concentration in the beech plot (mica schist parent material) in that layer is close to the total $\mathrm{Mn}$ concentration of gneiss, whereas the respective ones in the soils of the fir and maquis stand (flysch) are close to shale parent material quoted by Gilkes and McKenzie (1988).

\section{Available Mn}

The DTPA-extractable Mn in all plots had sufficient concentrations for plant growth if we take into account that the critical level (in mg kg${ }^{-1}$ ) is 3.5 for Mn (Nayar et al. 1985). In terms of the statistical comparisons, the available Mn was higher in the FH layer of the maquis plot and only the $0-10 \mathrm{~cm}$ layer under beech had the highest concentrations (Tab. 4). It is remarkable that in the FH layer, the total Mn concentration was higher in the beech plot, but the DTPA-extractable Mn for the same layer had higher concentration in the maquis plot. It is highly probable that the FH horizon in the beech plot had resistant organic compounds to DTPA. The maquis plot is situated in the Mediterranean zone where the climatic conditions are more favourable for decomposition in comparison with the mountainous areas. In deeper soil layers, the concentrations of available Mn in beech and fir did not differ significantly. The DTPA is a chelating agent and extracts the organically bound $\mathrm{Mn}$ as well as the $\mathrm{Mn}$ in the clay fraction. In the first soil layers, the $\mathrm{Mn}$ is mostly related to the soil organic matter. In deeper soils, the clay fraction becomes more important.

From Table 4, the percentages (\%) of available $\mathrm{Mn}$ over the total one can be calculated. In the FH horizons for the maquis stand, the percentage was 41.2 ; for the beech plot, 12.8; and for the fir plot, $21.4 \%$. As mentioned above, the high percentages in the maquis plot are because of the more efficient decomposition of organic matter. Deeper down the soil profiles, the percentages decreased reaching the lowest percentage in the $40-80 \mathrm{~cm}$ depth of the beech stand (6.6\%). It seems that DTPA is mostly related to the Mn bound to organic 
matter. For comparison reasons, we can mention that in agricultural acidic soils from the Madrid region (Spain), the percentage of DTPA-extractable Mn with regard to the total Mn ranged from 4.0 to $34.4 \%$, with an average of $13.9 \%$ (Obrador et al. 2007).

The Pearson correlations in Table 5 show the significant correlations of DTPA Mn with soil properties. The significant correlation of the DTPA-extracted Mn with organic $\mathrm{C}$ has to be expected. The organic $\mathrm{C}$ is closely related with CEC, so both relations are expected. Not all researchers have found similar relations. In a forest park near Teheran in Iran, Mahmoudabadi et al (2015) found a significant correlation of DTPA-extractable Mn with organic $\mathrm{C}$ and total $\mathrm{Mn}$. In Inceptisols in northwest India, Sharma et al. (2004) did not find a significant relationship between DTPA Mn and total Mn but only with $\mathrm{pH}$ and organic C. It seems that each ecosystem has its own relation, but some variables remain constantly influential such as the organic C. In our work, the DTPA extraction did not disclose the role of $\mathrm{pH}$, although it was the main factor for the high concentrations in the surface soil horizons under beech. We can infer that the DTPA-extracted Mn is a potential pool for the available $\mathrm{Mn}$, but it may not represent the actual uptake by trees. When soils become more acidic, the $\mathrm{pH}$ plays the most important role.

\section{Conclusions}

We have to reject the hypothesis that high Mn concentrations in tree leaves together with high Mn fluxes in litterfall are always related with high concentrations of available $\mathrm{Mn}$ in soils. It is a fact that high amounts of $\mathrm{Mn}$ in litterfall in the beech stand resulted in high concentrations of total $\mathrm{Mn}$ in the organic horizons of the soil in this forest type, but the fast decomposition of organic matter in the maquis zone gave higher concentrations of available $\mathrm{Mn}$ in the Ofh horizon. Only in the 0-10 cm soil layer, the beech plot had high concentrations of available Mn. Deeper down the soil profiles, the clay content affected the concentrations of available $\mathrm{Mn}$. As the beech trees do not take up Mn only from the Ofh and the $0-10 \mathrm{~cm}$ layers, we conclude that the low $\mathrm{pH}$ in the mineral soil of the deeper layers in the beech plot also contributes to Mn uptake.

\section{ACKNOWLEDGeMENTS}

The authors express their appreciation to the Ministry of Agriculture and Food, the Ministry of Environment and the European Commission, which financially sustain the Programme of "Effects of Atmospheric Pollutants on Forest Ecosystems" on the framework of which the current project was based. They also thank K. Kaoukis and A. Bourletsikas for their practical help in the field and generally in the programme and Mrs. Ch. Mitropoulou for her help with sample pre-treatment and analysis. Finally, the authors express their gratitude to the Forest Services of the areas where the forests stands are located for their invaluable practical assistance with all the problems encountered.

\section{CONFLict OF INTEREST}

The authors declare no conflict of interest with regard to this work.

\section{RefERENCES}

Astrup, M., Bulow-Olsen, A.B. 1979. Nutrient cycling in two Danish beech forest growing on different soil types. Holarctic Ecology, 2, 125-129.

Derome, J. 2000. Detoxification and amelioration of heavy-metal contaminated forest soils by means of liming and fertilisation. Environmental Pollution, 107, 79-88.

Duquesnay, A., Dupouey, J.L., Clement, A., Ulrich, E., Le Tacon, F. 2000. Spatial and temporal variability of foliar mineral concentration in beech (Fagus sylvatica) stands in northeastern France. Tree Physiology, 20, 13-22.

EC-UN/ECE-FBVA. 1997. Forest foliar condition in Europe, results of large-scale foliar chemistry surveys. European Commission-United Nations/Economic Commission for Europe, Brussels.

El-Jaoual, T., Cox, D.A. 1998. Manganese toxicity in plants. Journal of Plant Nutrition, 21, 353-386.

Encyclopedia Britannica. 2020. Maquis vegetation. Available at: https://www.britannica.com/science/ maquis-vegetation 
FAO-Unesco. 1988. Soil map of the world. FAO, Unesco, Rome.

Gandois, L., Probst, A. 2012. Localisation and mobility of trace metal in silver fir needles. Chemosphere, 87, 204-210.

Gilkes, R.J., McKenzie, R.M. 1988. Geochemistry and mineralogy of manganese soils. In.: Manganese in soils and plants (eds. D. Robin, R.D. Graham, R.J. Hannam, N.C. Uren). Springer, Dordrecht, 23-35.

GlatzeI, G., Kazda, M. 1985. Wachstum und Mineralstoffernährung von Buchen- und Ahornpflanzen (Fagus sylvatica, Acer platanoides) auf versauertem und schwermetallbelastetem Bodenmaterial aus dem Einsickerungsbereich des Stammablaufwassers in Buchenbeständen. Zeitschrift für Pflanzenernährung und Bodenkunde, 148, 429-438.

Grønflaten, L.K., Amundsen, L., Frank, J., Steinnes, E. 2005. Influence of liming and vitality fertilization on trace element concentrations in Scots pine forest soil and plants. Forest Ecology and Management, 213, 261-272.

Jonczak, J., Parzych, A. 2014. The content of heavy metals in the soil and litterfall in a beech-pine -spruce stand in Northern Poland. Archives of Environmental Protection, 40, 67-77.

Kabata-Pendias, A., Pendias, H. 2000. Trace elements in soils and plants. CRC Press, Inc. Boca Raton, Florida.

Kazda, M., Zvacek, L. 1989. Aluminium and manganese and their relation to calcium in soil solution and needles in three Norway spruce (Picea abies, L. Karst.) stands of Upper Austria. Plant and Soil, 114, 257-267.

Lindsay, W.L., Norvel, W.A. 1978. Development of a DTPA test for zinc, iron, manganese, and copper. Soil Science Society of American Journal, 42, 421-428.

Maas, E.V., Moore, D.P., Mason, B.J. 1969. Influence of calcium and magnesium on manganese absorption. Plant Physiology, 44, 796-800.

Madejón, P., Maraňón, T., Murillo, J.M. 2006. Biomonitoring of trace elements in the leaves and fruits of wild olive and holm oak trees. Science of the Total Environment, 335, 187-203.

Mahmoudabadi, E., Sarmadian, F., Moghaddam, R.N. 2015. Spatial distribution of soil heavy metals in different land uses of an industrial area of Tehran (Iran). International Journal of Environmental Science and Technology, 12, 3283-3298.

Matin, H.N., Jalali, M. 2017. The effect of waterlogging on electrochemical properties and soluble nutrients in paddy soils. Paddy and Water Environment, 15, 443-455.

Michopoulos, P., Economou, A., Nikolis, N. 2004. Soil extractable manganese and uptake in a natural fir stand grown on calcareous soils. Communications in Soil Science and Plant Analysis, 35, 233-241.

Mousavi, S.R., Shahsavari, M., Rezaei, M. 2011. A General overview on Manganese (Mn) importance for crops production. Australian Journal of Basic and Applied Sciences, 5, 1799-1803.

Nakos, G. 1983. Total concentrations of Mn, Zn and Cu in certain forest soils in Greece. Plant and Soil, 74, 137-140.

Nayyar, V.K., Sadana, U.S., Takkar, P.N. 1985. Methods and rates of application of $\mathrm{Mn}$ and its critical level for wheat following rice in coarse textured soils. Fertilizer Research, 8, 173-178.

Obrador, A., Alvarez, J.M., Lopez-Valdivia, LM., Gonzalez, D., Novillo, J., Rico, M.I. 2007. Relationships of soil properties with $\mathrm{Mn}$ and $\mathrm{Zn}$ distribution in acidic soils and their uptake by a barley crop. Geoderma, 137, 432-443.

Ohki, K. 1981. Manganese critical levels for soybean growth and physiological processes. Journal of Plant Nutrition, 3, 271-284.

Park, B.B., Yanai, R.D. 2009. Nutrient concentrations in roots, leaves and wood of seedling and mature sugar maple and American beech at two contrasting sites. Forest Ecology and Management, 258, 1153-1160.

Parzych, A., Mochnacky, S., Sobisz, Z., Kurhaluk, N., Pollakova, N. 2017. Accumulation of heavy metals in needles and bark of Pinus species. Folia Forestalia Polonica, Ser. A-Forestry, 59, 34-44.

Porter, G.S., Bajita-Locke, J.B., Hue, N.V., Strand, D. 2004. Manganese solubility and phytotoxicity affected by soil moisture, oxygen levels, and green manure additions. Communications in Soil Science and Plant Analysis, 35, 99-116.

Rengel, Z. 2015. Availability of Mn, Zn and Fe in the rhizosphere. Journal of Soil Science and Plant Nutrition, 15, 397-409. 
Sharma, B.D., Arora, H., Kumar, R., Nayyar, V.K. 2004. Relationships between soil characteristics and total and DTPA-extractable micronutrients in inceptisols of Punjab. Communications in Soil Science and Plant Analysis, 35, 799-818.

Sharma, B.D., Seth, A., Saini, R.S., Dhaliwal, S.S. 2011. Distribution of different forms of $\mathrm{Mn}$ and their association with soil properties in arid zone soils of Punjab, India. Archives of Agronomy and Soil Science, 57, 15-26.

Steiness, E., Friedland, A.J. 2005. Metal contamination of natural surface soils from long-range atmos- pheric transport: existing and missing knowledge. Environmental Reviews, 14, 169-186.

UN-ICP-Forests. 2020. International Co-operative Programme on Assessment and Monitoring of Air Pollution Effects on Forests operating under the UNECE Convention on Long-range Transboundary Air Pollution (CLRTAP) -(WWW.ICP-Forests. org).

Wyttenbach, A., Tobler, L., Bajo, S. 1991. Correlation between soil $\mathrm{pH}$ and metal contents in needles of Norway spruce. Water Air and Soil Pollution, 57/58, 217-226. 